Status Report 2016-2019

\title{
Recent Advances in Understanding Neogene Climatic Evolution: Indian Perspective
}

\author{
A D SINGH ${ }^{1, *}$, A K GHOSH ${ }^{2}$, R C MEHROTRA ${ }^{2}, \mathrm{R} \mathrm{PATNAIK}^{3}$ and M TIWARI ${ }^{4}$ \\ ${ }^{1}$ Centre of Advanced Study in Geology, Banaras Hindu University, Varanasi, India \\ ${ }^{2}$ Birbal Sahni Institute of Palaeosciences, Lucknow, India \\ ${ }^{3}$ Centre of Advanced Study in Geology, Panjab University, Chandigarh, India \\ ${ }^{4}$ ESSO-National Centre for Polar and Ocean Research, Goa, India
}

(Received on 18 August 2019; Accepted on 10 September 2019)

\begin{abstract}
This article presents an overview of the research work done during 2015-2019 on the South Asian/Indian monsoon climate variability, based on the Neogene terrestrial and marine proxy records. The paleoclimatic and paleoceanographic records provide better insights into our current understanding of timing of initiation/intensification of the Indian monsoon system; its evolution and seasonal variability pattern through time and underlying mechanisms; and impacts on paleobiogeography of terrestrial fauna and flora and physico-chemical and biological processes in the northern Indian Ocean. The Neogene upliftment history of the Himalaya was reconstructed based on detailed analysis of fossil flora from Himalayan sequences and a link between step wise uplift of Himalaya-Tibetan plateau and Indian summer monsoon intensification was established. The rainfall pattern in the northeast India during the Neogene period was quantified; and the new data suggest the presence of rainfall in the region since 11.6 Ma. $\delta^{13} \mathrm{C}$ record of pedogenic nodules in Siwalik succession provides evidence of major shift in vegetation between $\sim 2.8 \mathrm{Ma}$ and $1.1 \mathrm{Ma}$ due to large variation in temperature and precipitation. New results of the multiproxy based paleoceanographic studies carried out on sediment cores collected during recent IODP expeditions in the Arabian Sea and Bay of Bengal, have major implications on the evolution of the Indian monsoon and dynamics of its seasonal variations in the Neogene. The sedimentological and geochemical records from carbonate platform of the Maldives suggest an abrupt onset of modern monsoon circulation at $\sim 12.9 \mathrm{Ma}$, which cannot be entirely explained by the Himalayan tectonics as many believed earlier. It appears that the global climate also controls Indian monsoon circulation, in addition to the tectonics. Record of past changes in the Arabian Sea denitrification driven mainly by monsoon-wind induced productivity and water column ventilation condition, reveals that the Indian monsoon intensified during 2.8-3.2 Ma. Recently, based on the integrated multiple proxy records it was inferred that seasonal monsoon circulation was weak during 1.85-2.7 Ma, subsequently followed by the intensification of winter monsoon between $\sim 1.65$ and $1.85 \mathrm{Ma}$, attributed to the development of strong zonal and meridional circulations due to enhanced E-W Pacific temperature gradients.
\end{abstract}

Keywords: Neogene; Indian Monsoon; Terrestrial; Marine; Proxy Record

\section{Introduction}

The Neogene has been one of the most crucial periods of the geological history, characterized by the major reorganization of land and sea, evolution of mountain chains and development of present day ocean and atmospheric circulations. In the context of the Indian subcontinent, the Neogene period has witnessed final closure of Tethys associated with the major Himalayan uplift; and the evolution of the Bengal Fan and the Andaman Sea. The plate tectonics leading to

\footnotetext{
*Author for Correspondence: E-mail: arundeosingh@yahoo.com
}

the closure of ocean gateways in low-latitude region during the Neogene had dramatic effects on oceanatmosphere circulation patterns, tropical climate, paleobiogeography of marine and terrestrial fauna and flora. Existing geological evidences strongly suggest a major shift from zonal type climatic patterns of the Paleogene to the monsoonal pattern in Asia during the Neogene (Guo et al., 2008; Wang et al., 2012). The Asian monsoon with its two subsystems (South Asian/Indian and East Asian) is one of the important 
components of the global climate, which determines global hydrological cycle and heat budget.

As economy of Asian countries by and large depends on monsoon, there has been growing interests amongst the geoscientists, climatologists, oceanographers and ocean-climate modelers in recent decades to study evolution of monsoon, its variability pattern and associated ocean-atmospheric processes and driving mechanisms on longer to short time scales (tectonic and orbital to interannual). Furthermore, it is being increasingly realized that the regional monsoon systems should be viewed and investigated as part of a global system (Wang et al., 2014). Therefore, in order to better understand the dynamics of monsoon variations, it is essential to analyze pattern of variation in regional monsoon systems (eg. Asian monsoon) across the different time scales and its causal mechanisms in global perspective.

\section{Paleoclimate Reconstructions: Marine and Terrestrial Proxies}

The timing and conditions under which monsoon circulation initiated/intensified are some of the key issues in paleomonsoon/paleoclimate studies. Several evidences derived from marine and terrestrial records suggest that the Asian monsoon intensified substantially in the Late Miocene at $\sim 8 \mathrm{Ma}$ (Kroon et al., 1991; France-Lanord and Derry, 1994; Quade et al., 1989). This view was supported by climate model and tectonic studies indicating that major upliftment of the Himalaya-Tibetan plateau in Late Miocene played a role for the intensification of the Asian Monsoon (Kutzbach et al., 1989, 1993; Harrison et al., 1992; Prell and Kutzbach, 1997; An et al., 2001). However, a recent study from the Arabian Sea by Huang et al. (2007) does not support the intensification of summer monsoon in the Late Miocene. The existence of Asian monsoon further back in time during the Early Miocene was suggested by Clift et al. (2010) based on the Himalayan erosion/ weathering records in marine sediment. The planktic foraminiferal assemblage based paleoceanographic records from the northern Indian Ocean DSDP sites indicate that the intensification of monsoon occurred during 11-12 Ma, as a consequence of blocking of Central Equatorial System due to effective closure of Indonesian seaway (Srinivasan and Singh, 1991). Hence, the issue of timing of the onset/intensification of the modern Asian monsoon system is not yet fully resolved.

In recent years, a growing interest in better understanding the Quaternary climate instability pattern, has resulted in an increased number of paleomonsoon records on inter-annual to orbital time scales employing micropaleontological, geochemical and sedimentological tracers from marine and terrestrial archives. Indian scientists and their research groups have made significant contributions on South Asian/Indian paleomonsoon variability using variety of high resolution proxy records from the natural archives (marine and lacustrine sediments, cave speleothems, tree rings, fluvio-glacial sediments, loess, ice-cores) holding past climate signatures (Patnaik et al., 2012; Gupta et al., 2012; Singh et al., 2016 and references there in). The proxies used in paleomonsoon reconstructions are related to the two aspects viz monsoonal wind strength and monsoon precipitation. Over the years, there has been an increase in paleomonsoon reconstructions based on rain based proxies. Because, the surface hydrography and productivity in the two basins (Arabian Sea and Bay of Bengal) bordering the Indian subcontinent are largely controlled by the seasonal patterns of monsoon winds and rain/runoff, the proxies from ocean floor sediment are widely used to record both changes in monsoon circulation and precipitation. Whereas, monsoon proxies from terrestrial archives mainly record the rainfall/precipitation. Earlier studies provide ample evidences for links between inter-annual to decadal scale Indian summer monsoon variability and equatorial Indo-Pacific climate and ENSO. Apart from the teleconnections between paleomonsoon variability and high latitude northern Hemisphere climate on centennial to millennial scale, previous studies have also suggested dominant solar control over short term perturbations in the Indian monsoon.

\section{Neogene Evolution of South Asian/Indian Monsoon Climate}

We have by now a reasonable understanding about the Indian summer monsoon dynamics and variability in the Quaternary period. But, the current picture of seasonal monsoon variability remains incomplete, as we have only a few records of past changes in the winter monsoon limited to the Late Pleistocene. Furthermore, our knowledge about the timing and 
conditions under which seasonal monsoon circulations evolved and how the monsoon system responded to changes in external and internal forcing of Earth's climate on longer time scales beyond the Quaternary, are not sufficient. Nevertheless, important contributions on the Neogene Indian monsoon variability and its impact on paleobiogeographic evolution of fauna and flora of the Indian subcontinent have also been made in recent years using pedological, sedimentological, geochemical and paleontological approaches (Patnaik et al., 2012; Patnaik and Prasad, 2016 and references there in). In order to explore the driving mechanism of monsoon variabilities and to address various outstanding issues of monsoon evolution on different time scales, the scientific drilling in critical regions of the Asian monsoon system was carried out recently by the International Ocean Discovery Program (IODP). Active participation by the Indian scientists in these IODP expeditions has accelerated their paleomonsoon/paleoclimate studies beyond the Quaternary, further back in time for the entire Neogene period.

This review report provides a glimpse of the significant contributions on the "Neogene evolution of the Indian/South Asian monsoon system" made by the Indian scientists and their research groups during 2015-2019.

\section{Links Between Himalayan Tectonics, Paleo- climate and Paleobiogeography of Fauna and Flora}

The uplift of Himalaya-Tibetan plateau during the Neogene has not only influenced the Asian monsoon, but also the global climate (Wang et al., 2014). It is widely accepted that the step wise Himalayan-Tibetan uplift in the geological past has significantly affected the characteristics of Asian monsoon circulations and the orography. Therefore, a thorough knowledge of Himalayan upliftment history is crucial for understanding the mechanism which links the elevation of Tibetan plateau and the climate. The modeling studies have provided valuable information on the elevation history of Tibetan plateau (Tapponnier et al., 2001; Molnar et al., 2010). In recent years, efforts have been made for quantitative estimation of the paleo-elevation of Tibet, using geophysical data and biological evidences, however, the results from these two methods are different. It has been realized that an extant plant fossil taxon is related to a unique ecological niche; hence an ideal tracer of past environment including the elevation existed at that time. Sun et al. (2015) discovered Berberis leaf fossils from Early Miocene sediments of northern Tibet and inferred that the area was uplifted $\sim 2-3 \mathrm{~km}$ in the last $17 \mathrm{Ma}$. Spatial distribution and characteristics of fauna and flora in Himalayan region are largely dependent on climate and seasonality of Indian monsoon rainfall. Hence, the evolution, diversification and dispersal of Himalayan flora and fauna are strongly associated to the past changes in monsoonal climate and rainfall.

The mega-remains of land plants and their leaf architecture are considered to be reliable proxies for the quantitative reconstruction of the paleoclimate. In recent years, several studies have been carried out for paleovegetation and paleoclimate reconstructions based on detailed analysis of fossil flora from the Neogene sedimentary sequences in different regions of Himalaya following various approaches like Coexistence Approach (CA), Climate Leaf Analysis Multivariate Program (CLAMP) and Leaf Margin Analysis (LMA) (eg. Srivastava et al., 2017; Khan et al., 2018). Based on the leaf morphology and climate relationship, Ding and coworkers (2017) have inferred that uplift of the Himalaya played an important role in the intensification of Indian Summer Monsoon during the Miocene. Using CA approach on floral assemblages in the Late Miocene-Early Pliocene sediment of Mizoram, Srivastava et al. (2017) for the first time quantified the Neogene rainfall pattern of northeast India and inferred that the monsoonal rain in area had been present in the region since 11.6 Ma. The inferences drawn by these workers were in line with the previous studies from Arunachal Pradesh using CLAMP analysis approach (Khan et al., 2014). Srivastava et al. (2018a) have also quantified the Middle -Late Miocene climate of Nepal and deciphered that the Indian Summer Monsoon (ISM) precipitation did not vary during this time interval, however, the winter season rainfall decreased significantly in the Late Miocene. The reconstructed climate data also indicate that high temperature and low precipitation during the winter season in the Late Miocene might have enhanced forest fire, which favoured the expansion of $\mathrm{C}_{4}$ plants over $\mathrm{C}_{3}$ plants during the period. 
Furthermore, Srivastava et al. (2018b) based on their new report of the fossil wood of Lagerstroemia L. f. of the family Lythraceae from the Late Miocene sediments of Trans-Himalayan region (Kargil district, Jammu and Kashmir), suggested that the climate of the region was warmer and wetter and the elevation of the area was lower in contrast to that of the modern day elevation of $\sim 3559 \mathrm{~m}$. Additionally, the palynological records of the sedimentary sequences of Siwalik Group provided valuable information of paleovegetation history and its linkage to the climate variability during the Neogene (eg. More et al., 2016).

The Neogene-Quaternary freshwater Siwalik deposits of the sub-Himalayas exhibit an excellent record of well developed paleosols. The pedogenic nodules preserved in these paleosols are widely considered as good archives for paleoecological and paleoclimatological reconstructions. The isotopic signature of rainfall, temperature and vegetation changes can be traced in only in situ pedogenic nodules. The $\delta^{13} \mathrm{C}$ record of pedogenic carbonate is a robust proxy, widely used for characterization of past changes in land vegetation. Quade et al. (1989) using this proxy in the Siwalik paleosols, identified a major shift in $\mathrm{C}_{3}$ to $\mathrm{C}_{4}$ biomass in the Himalayan foreland at $\sim 7 \mathrm{Ma}$, associated to major ecological changes. The major expansion of $\mathrm{C}_{4}$ plants in the Late Miocene has been explained by these workers to the enhanced aridity in the region. Patnaik et al. (2012) in their detailed studies on the Indian Siwalik paleosols have suggested several phases of monsoon intensification with its maxima at $\sim 11 \mathrm{Ma}$, between 6 and $3 \mathrm{Ma}$ when $\mathrm{C}_{3}$ type vegetation was replaced by the $\mathrm{C}_{4}$ type plants (Patnaik et al., 2012). Recently, Kotla et al. (2018) investigated a Neogene-Quaternary section situated around Chandigarh, for stable isotopes of in situ pedogenic nodules. The section spans about 2.8$0.6 \mathrm{Ma}$, and rich in fossil vertebrates. This section is comprised of $\sim 1030 \mathrm{~m}$ thick fluvial sequence, with $\sim 60 \mathrm{~m}$ of fine to medium grey sandstones and variegated mudstones/siltstones belonging to the Tatrot Formation lie at the base, followed by a $\sim 380 \mathrm{~m}$ thick brown and multistoried pebbly sandstone and weakly pedogenised mudstones belonging to Pinjor Formation. Overlying these Pinjor deposits occur $\sim 575 \mathrm{~m}$ of Boulder Conglomerate Formation (Kumaravel et al., 2005). Following the mathematical isotopic mixing model approach in their study, Kotla et al. (2018) suggested $>70 \%$ contribution of $\mathrm{C}_{4}$ plants between $\sim 2.8$ and $1.1 \mathrm{Ma}$, whereas $30-60 \%$ of $\mathrm{C}_{3}$ plants occupied the landscape between 2.15 and $1.7 \mathrm{Ma}$ (Fig. 1). The $\delta^{13} \mathrm{C}$ values from younger nodules indicate a significant contribution by $\mathrm{C}_{3}$ plants between 1.1 and $0.6 \mathrm{Ma}$. The variation in temperature throughout the time period is about $5.9^{\circ} \mathrm{C}$ between $2.7 \mathrm{Ma}$ and $0.6 \mathrm{Ma}$. This large amount of change in temperature during this period may be related to climate change or variation in the amount of precipitation in this area. However, stable carbon and oxygen isotope studies of soil carbonate nodules from the PliocenePleistocene Siwalik sediments indicate that the climate was not the only factor influencing distribution of $\mathrm{C}_{4}$ plants (Ghosh et al., 2018). Several sedimentological

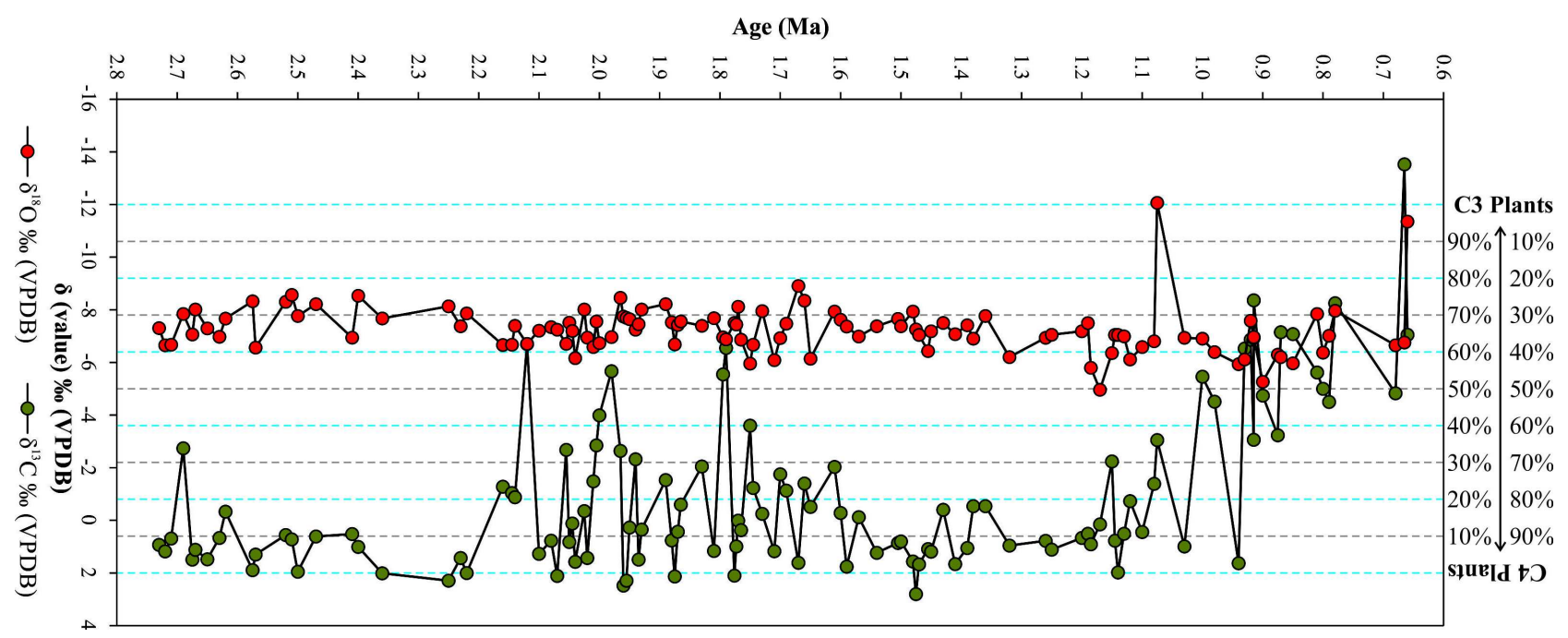

Fig. 1: Composite plot of isotope ratios against age of soil carbonate nodules from Ghaggar River Section. The dotted line represents the contribution of $\mathrm{C}_{3}$ and $\mathrm{C}_{4}$ plants throughout the time scale based on $\delta^{13} \mathrm{C}$ values only (Kotla et al., 2018) 
and geomorphological studies in the Himalayan foreland basins have also been conducted in recent years, to understand the influence of tectonics and climate on sedimentary architecture; erosional and depositional processes (eg. Goswami, 2017; Goswami and Deopa, 2018).

\section{Records of Past Changes in Ocean-Climate During the Neogene}

Seasonally reversing monsoon winds and monsoonprecipitation greatly influence hydrography, nutrient distribution and biological productivity and sediment deposition in the ocean basins surrounding the south Asian continent. Therefore, sediment archives of these basins are ideal for paleoceanographic and paleoclimatic reconstructions. The uplifted Neogene sequences of Andaman-Nicobar (AN) being represented primarily by marine deep water facies, are rich in well preserved and diverse microfauna and flora (Sharma and Srinivasan, 2007). The Neogene sediments of AN contain both the calcareous and siliceous microfossils, viz. foraminifera, radiolaria, diatoms, nannoplanktons, ostracoda, silicoflagellates, pteropods etc. (Sharma and Srinivasan, 2007). Of these, foraminifera have been extensively investigated by many previous workers for the establishment of biostratigraphy and paleoenvironmental interpretations (Sharma and Srinivasan, 2007 and references there in). In recent years, other microfossil groups (calcareous nannofossils and siliceous diatoms, radiolarian, silicoflagellates) also received attention of Indian micropaleontologists, because of their immense potentiality in paleoceanographic and paleoclimatic studies. The microfossil (calcareous nannofossil, radiolaria, diatom) assemblages recovered from selected Neogene sections of Andaman-Nicobar Islands have been analyzed both qualitatively and quantitatively and paleoclimatic inferences were drawn based on abundance records of ecologically sensitive species/groups (Chakraborty and Ghosh, 2016, 2017 and Chakraborty et al., 2018). The predominance of an upwelling taxon Thalassionema nitzschioides in Late Miocene diatom assemblage suggests upwelling induced high phytoplankton productivity and strong monsoonal activity (Chakraborty and Ghosh, 2016) (Fig. 2), which is in conformity with earlier reports from the northern Indian Ocean. Abundant occurrence of warm water taxa in calcareous nannofossil and diatom assemblages during 15-16.4 Ma, has been interpreted by Chakraborty et al. (2018) as the period of Miocene Climate Optimum (MCO) (Fig. 2). Chakraborty and Ghosh (2017) further reported a reduction in abundance and diversity of siliceous microfossils during the Early Pliocene, which they suggested to be an event of biogenic silica (BSi) crash, attributed probably due to the nutrient deficient condition (Fig. 2). This report of BSi crash in the Early Pliocene is consistent with previous studies of the Andaman Sea and Bay of Bengal (Cawthern et al., 2014).

Scientific ocean drilling since its initiation as the Deep Sea Drilling Project (DSDP) in late sixties, and subsequently as the Ocean Drilling Program (ODP) followed by Integrated Ocean Drilling Program (IODP), has significantly contributed to our understanding of the paleoceanographic evolution of

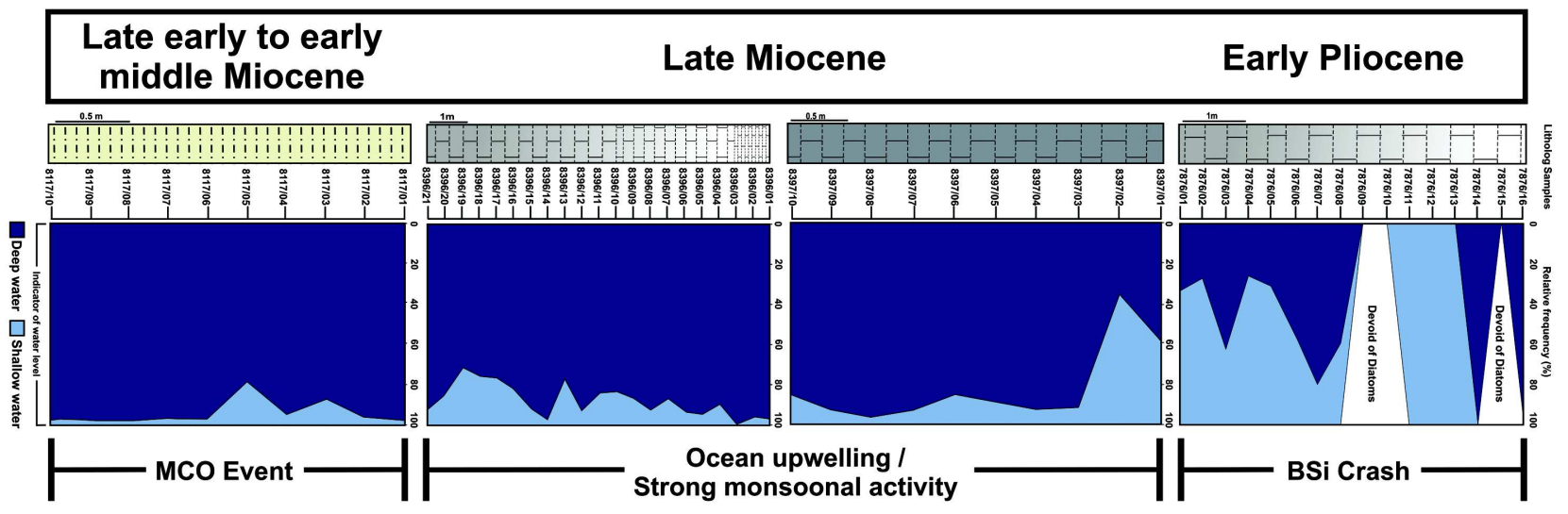

Fig. 2: Events of MCO, ocean upwelling and BSi crash during Early Miocene to Early Pliocene based on sea level fluctuations derived from planktonic/benthic ratio of diatoms from Andaman and Nicobar Basin (modified after Chakraborty and Ghosh, 2016, 2017 and Chakraborty et al., 2018) 
world oceans and their role in regulating the Earth's climate and importance in affecting global water and heat budgets. In recent years, a considerable importance was given to the monsoon dominated regions of tropical oceans, because this is the area of a major source of water vapour to the higher atmosphere, hence producing a positive feedback to climate shift. Investigations of long, undisturbed and relatively continuous cores recovered during various DSDP/ODP/IODP expeditions enabled international scientific community to bring out important results pertaining to the land-ocean interactions and the evolution of monsoon systems and their variability patterns both in space and time. But, the response of monsoons to external forcings and internal feedback and driving mechanisms of monsoon variability and its teleconnections are not yet fully understood. Most recently (2013-2016), a series of the IODP (International Ocean Discovery Program, earlier known as Integrated Ocean Drilling Program) expeditions conducted drilling in the northern Indian Ocean targeting areas crucial to the Asian monsoon (Expeditions 353, 354 in Bay of Bengal; 355 in the Arabian Sea; and 359 in Maldives) and its possible linkage to the evolution of Himalaya and Tibet (Tada et al., 2018). The broad and common objective of these expeditions was to address long-lasting questions such as: when and how the Indian monsoon subsystem developed; how it has evolved; what was its variability pattern and seasonality through time, whether both the subsystems (Indian/South Asian and East Asian) of the Asian monsoon system behaved differently through time; and understanding the underlying mechanism and forcing factors for monsoon variability?. Indian scientists from various universities and research institutes have participated in these expeditions, carried out on-board studies and further continuing their research on the core samples recovered during expeditions, in collaboration with national/international research groups. The research findings based on the studies of core samples recovered during these expeditions with contributions of Indian scientists made so far are summarized here.

IODP expedition 355 in the Laxmi Basin of eastern Arabian Sea aimed to examine Himalayan tectonics, weathering and erosion on South Asian/ Indian monsoonal climate over long to shorter time scales. About $1700 \mathrm{~m}$ sediment record was recovered by drilling through Indus Fan at the two sites. Based on the paleoceanographic and paleoclimatic studies carried out on IODP 355 samples using multiproxy approach, significant contributions were made on the monsoon evolution during the Neogene period and its impact on the eastern Arabian Sea oceanography. New results provided insights into our current understanding on tectonic-climatic interactions and their overall impact on weathering and erosion. A precise chronostratigraphy and age model of sedimentary sequences is prerequisite to paleoceanographic and paleoclimatic studies. Routledge et al. (2019) revised the shipboard age model of the deep sea sequences at the two IODP sites (U1457 and U1456) by integrating the multiple microfossil biostratigraphies with paleomagnetic and geochemical data. The refined, integrated chronostratigraphy also enabled them to revise timings and intervals of deep sea hiatuses at the IODP sites.

South Asian/Indian monsoon-induced high surface water productivity coupled with poor ventilation of intermediate water results in strong denitrification within the oxygen minimum zone (OMZ) in the eastern Arabian Sea (EAS). One of the end products of denitrification is $\mathrm{N}_{2} \mathrm{O}$, which is a greenhouse gas that is $\sim 300$ times more powerful than $\mathrm{CO}_{2}$. Despite the significance of denitrification in global climate change, no long-term record of its evolution in the Arabian Sea during the MiocenePliocene period existed till date; the longest record available goes back to 1 million years from the western Arabian Sea (Altabet et al., 1999). To fill this gap, Tripathi et al. (2017) studied various denitrification $\left(\delta^{15} \mathrm{~N}\right.$ of sedimentary organic matter, SOM), provenance $\left(\delta^{13} \mathrm{C}\right.$ of SOM, $\mathrm{C} / \mathrm{N}$ ratio) and productivity (total organic carbon (TOC) and total nitrogen (TN)) proxies in sediment record of the IODP Site U1456, spanning the last $10 \mathrm{Myr}$ (Fig. 3). Their study suggests that the Indian monsoon induced productivity predominantly governs denitrification in the eastern Arabian Sea on longer time scales. Tripathi et al. (2017) inferred that the denitrification in EAS, coupled with the South Asian/Indian monsoon circulation was persistently weak from $\sim 10.2$ to $3.1 \mathrm{Ma}$. Hence, according to their studies, the monsoon did not intensify at $\sim 8 \mathrm{Ma}$, as has been suggested by many previous workers. They also provided the first evidence of denitrification and South Asian monsoon intensification at $\sim 3.2-2.8 \mathrm{Ma}$ which broadly corresponds to the Mid-Pliocene Warm Period 


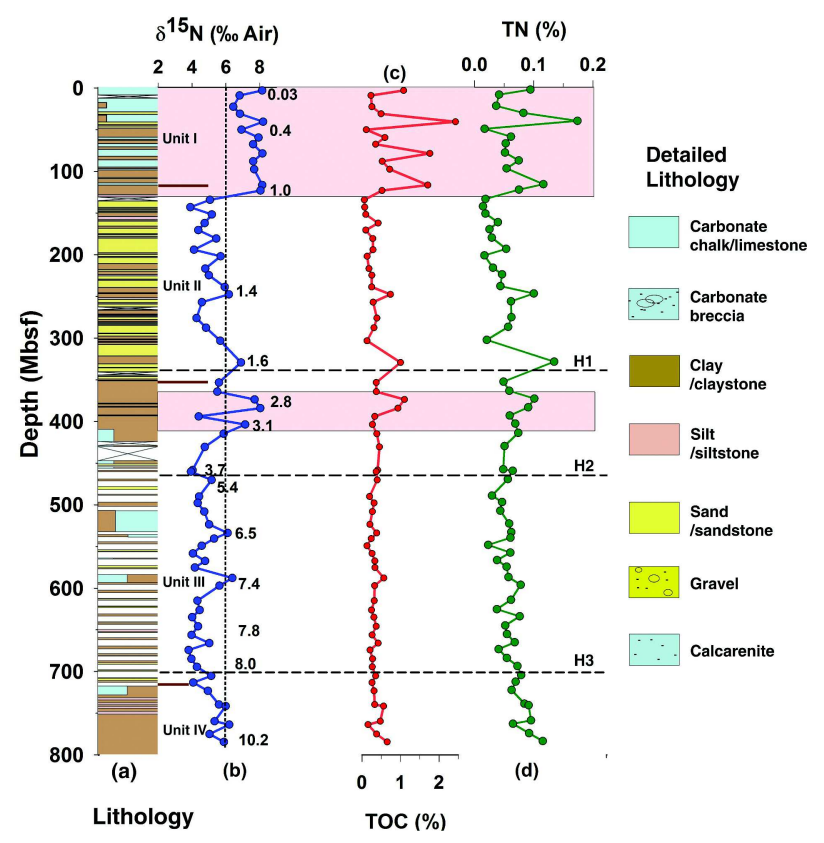

Fig. 3: Downcore variability of denitrification $\left(\delta^{15} N\right)$ and productivity (TN, TOC) at IODP Site U1456 spanning the last 10 Myr. The Indo-Arabic numerals in the first panel show the ages (in Million Years Ago, Ma) based on biostratigraphy and magnetostratigraphy. The shaded regions depict the two periods of denitrification and enhanced productivity in the Eastern Arabian Sea. The vertical dashed line in the first panel depicts the $6 \%$ value (denitrification threshold) while the three horizontal dashed lines represent three hiatuses. The lithology of the core and its division into four units based on sediment properties is also shown (modified after Tripathi $e t$ al., 2017)

(MPWP), a period of global warmth with $\mathrm{CO}_{2}$ levels similar to the present. Based on their multiple proxy records, Tripathi et al. (2017) further suggested that the permanent feature of denitrification in EAS like today, was attained at 1.0 Ma. Sediments recovered from the expedition 355 IODP sites provided an opportunity to record the degree of terrestrial contribution to the sediment deposited at the sites located at distal end of the Indus Fan. Using record of $\delta^{13} \mathrm{C}$ of sedimentary organic carbon at IODP site U1457, it has been possible to infer past changes in environment in the catchment area of Indus River since the late Miocene (Khim et al., 2019). Khim et al. (2019) also reported general low values of $\delta^{13} \mathrm{C}$ from the Late Miocene to Late Pleistocene, which they inferred to be related to a consistent contribution of terrestrial organic matter attributed to the $\mathrm{C}_{3}$ land plants predominantly occurring in the catchment areas.
However, they observed significantly lower values during 7-8 Ma suggesting larger input of $\mathrm{C}_{3}$ plant during this time interval. On the contrary, a significant increase in $\delta^{13} \mathrm{C}$ at $\sim 7 \mathrm{Ma}$ and subsequently followed by its relatively high values from $\sim 7$ to $2 \mathrm{Ma}$ are suggestive of increased $\mathrm{C}_{4}$ biomass, probably related to the enhanced terrestrial aridity in the Himalayan foreland (Khim et al., 2019). In order to better understand the dynamics and evolution of seasonality in the Indian monsoon, it is essential to study past changes in winter monsoon and its evolution through time. The eastern Arabian Sea sediment records are ideal to investigate winter monsoon variability, as hydrography and productivity in this region is primarily driven by the northeasterly winter monsoon winds. In recent past, some important studies on winter monsoon variation on millennial to orbital time scales have been carried out based on late Quaternary foraminiferal assemblages, $\mathrm{Mg} / \mathrm{Ca}$ based temperature and stable oxygen isotope records from the central part of eastern Arabian Sea Indian margin (Singh et al., 2011, 2018; Cabarcos et al., 2014; Anand et al., 2008). But, until recently no record was available for the crucial period of climatic transition from the Late Pliocene to the Early Pleistocene, when a major reorganization of atmospheric circulation from a weak to strong zonal and meridional atmospheric circulations took place (eg. Etourneau et al., 2010). Satpathy et al. (2019), based on their detailed studies of planktic foraminiferal assemblage record combined with isotopic and $\mathrm{Mg} / \mathrm{Ca}$ sea surface temperature records at IODP site U1457, inferred weak southwest (summer) and northeast (winter) monsoon circulations during 1.85-2.7 Ma. They further suggested an intensification of winter monsoon circulation between $\sim 1.65 \mathrm{Ma}$ and $1.85 \mathrm{Ma}$, which they attributed to the development of strong Walker and Hadley circulations due to enhanced equatorial East-West Pacific temperature gradients (Satpathy et al., 2019).

The IODP expedition 359 drilled eight sites in the carbonate platform of the Maldives in the Indian Ocean to study the sea level fluctuations and paleoceanographic changes and their implications to the evolution of South Asian/Indian monsoon circulations during the Neogene. Present day ocean currents in the Maldives are directly linked to the seasonally reversing monsoon winds. Therefore, the successions of current deposits over the carbonate platform are ideal archive to study past changes in 
the regional wind system. The sedimentological, geochemical and geophysical data of the IODP site U1468, provided new insights into current knowledge of the initiation/intensification of the present day Indian monsoon circulation and its relationship to the global Neogene climate (Betzler et al., 2016, 2018). Betzler et al. (2016) observed abrupt shift in the sedimentary and geochemical records at $\sim 12.9 \mathrm{Ma}$, which they inferred to be related to the onset of modern current system over the Maldives in response to the initiation of South Asian/Indian monsoon wind circulation. The abrupt onset of modern monsoon winds at $\sim 12.9 \mathrm{Ma}$ over a short period, cannot be solely explained by the Himalayan-Tibet tectonics. These authors suggested strong influence of global climate on the strengthening of South Asian monsoon, in addition to the tectonics. Intriguingly, the timing of onset/strengthening of

\section{References}

Altabet M A, Murray D W and Prell W L (1999) Climatically linked oscillations in Arabian Sea denitrification over the past $1 \mathrm{My}$ : Implications for the marine $\mathrm{N}$ cycle Paleoceanography 14 732-743

An Z, Kutzbach J E, Prell W L and Porter S C (2001) Evolution of Asian monsoons and phased uplift of the HimalayaTibetan plateau since Late Miocene times Nature 411 6266

Anand P, Kroon D, Singh A D, Ganeshram R, Ganssen G and Elderfield $\mathrm{H}$ (2008) Coupled seasurface-seawater $\delta^{18} \mathrm{O}$ reconstructions in the Arabian Sea at the millennial scale for the last $35 \mathrm{ka}$ Paleoceanography 23 PA4207 Doi: 1029/ 2007PA001564

Betzler C, Eberli G P, Kroon D, Wright J D, Swart P K, Nath B $\mathrm{N}$, Alvarez-Zarikian C A, Alonso-García M, Bialik O M, Blättler C L, Guo J A, Haffen S, Horozal S, Inoue M, Jovane L, Lanci L, Laya J C, Mee A L H, Lüdmann T, Nakakuni M, Niino K, Petruny L M, Pratiwi S D, Reijmer J J G, Reolid J, Slagle A L, Sloss C R, Su X, Yao Z and Young J R (2016) The abrupt onset of the modern South Asian Monsoon winds Scientific Reports 629838 Doi. org/10.1038/srep29838

Betzler C, Eberli G P, Lüdmann T, Reolid J, Kroon D, Reijmer J J G, Swart P K, Betzler C, Eberli G P, Wright J, Young J R, Alvarez-Zarikian C and Alonso-García M (2018) Refinement of Miocene sea level and monsoon events from the sedimentary archive of the Maldives (Indian Ocean) Progress in Earth and Planetary Science 5 1-5 monsoon wind system closely precedes the end of the Middle Miocene climate transition, a period of global cooling and growth of the East Antarctic Ice Sheet (Betzler et al., 2016), which supports the view of climate control on the monsoon evolution.

More results of ongoing studies on core samples taken during IODP expeditions targeted to monsoon regions of the Indian Ocean, expected over the coming years will significantly improve our understanding of monsoonal processes.

\section{Acknowledgements}

We thank Prof. D M Banerjee and Prof. S K Bajpai for the invitation to contribute to this volume. MT thanks the Ministry of Earth Sciences for support.

Cabarcos E, Flores J A, Singh A D and Sierro F J (2014) Monsoonal dynamics and evolution of the primary productivity in the eastern Arabian Sea over the past 30 ka Palaeogeography, Palaeoclimatology, Palaeoecology 411 249-256

Cawthern T, Johnson J E, Giosan L, Flores J A, Rose K and Solomon E (2014) A late Miocene-early Pliocene biogenic silica crash in the Andaman Sea and Bay of Bengal Marine and Petroleum Geology 58 490-501

Chakraborty A and Ghosh Amit K (2016) Ocean upwelling and intense monsoonal activity based on late Miocene diatom assemblages from Neil Island, Andaman and Nicobar Islands, India Marine Micropaleontology 127 26-41

Chakraborty A and Ghosh A K (2017) Siliceous Microfossils of the Neogene Sediments from Northern Indian Ocean In Micropaleontology and its Applications, Kathal P, Nigam R and Talib A (eds), Scientific Publishers, India pp 163189

Chakraborty A, Ghosh A K, Dey R, Saxena S and Mazumdar A (2018) Record of Miocene Climate Optimum in the Northeast Indian Ocean: Evidence from the microfossils Palaeobiodiversity and Palaeoenvironments Doi org/10 1007/s12549-018-0342-3

Clift P D, Tada R and Zheng H (2010) Monsoon evolution and tectonics-climate linkage in Asia: an introduction Geological Society, London, Special Publications 342 1-4

Etourneau J, Schneider R, Blanz T and Martinez P (2010) Intensification of the Walker and Hadley atmospheric circulations during the Pliocene-Pleistocene climate transition Earth and Planetary Science Letters 297 103110 
France-Lanord C and Derry LA(1994) $\delta^{13} \mathrm{C}$ of organic carbon in the Bengal Fan: Source evolution and transport of $\mathrm{C}_{3}$ and $\mathrm{C}_{4}$ plant carbon to marine sediments Geochimica et Cosmochimica Acta 58 4809-4814

Ghosh S, Sanyal P, Sangode S J and Nanda A C (2018) Substrate control of $\mathrm{C}_{4}$ plant abundance in the Himalayan foreland: A study based on inter-basinal records from PlioPleistocene Siwalik Group sediments Palaeogeography Palaeoclimatology Palaeoecology 511 341-351

Goswami P K (2017) Depositional processes in the distal part of a large alluvial fan's feeder channel in Himalayan foothills, India Geological Journal 52 733-744

Goswami P K and Deopa T (2018) Lithofacies characters and depositional processes of a Middle Miocene lower Siwalik fluvial system of the Himalayan foreland basin, India Journal of Asian Earth Sciences 162 41-53

Gupta A K, Sinha D K, Singh A K, Naidu P D, Saraswat R and Rai A K (2012) Indian Contributions in the field of Paleoceanography Proceedings of the Indian National Science Academy 78 313-319

Guo Z T, Sun B, Zhang Z S, Peng S Z, Xiao G Q, Ge J Y and Yin Q Z (2008) A major reorganization of Asian climate by the early Miocene Climate of the Past 4 153-174

Harrison T M, Copeland P, Kidd W S F and Yin A N (1992) Raising Tibet Science 255 1663-1670

Huang Y S, Clemens, S C, Liu W G, Wang Y and Prell W L (2007) Large-scale hydrological change drove the late Miocene $\mathrm{C}_{4}$ plant expansion in the Himalayan foreland and Arabian Peninsula Geology 35 531-534

Khan M A, Spicer R A, Bera S, Ghosh R, Yang J, Spicer T E V, Guo SX, Tao S, Fr'ed'eric J and Grote PJ (2014) Miocene to Pleistocene floras and climate of the Eastern Himalayan Siwaliks, and new palaeoelevation estimates for the Namling-Oiyug Basin, Tibet Global and Planetary Change 113 1-10

Khan M A, Bera M, Spicer R A, Spicer T E V and Bera S (2018) Floral diversity and environment during the middle Siwalik sedimentation (Pliocene) in the Arunachal sub-Himalaya Palaeobiodiversity and Palaeoenvironments https://doi. org/10.1007/s12549-018-0351-2

Khim B K, Lee J, Ha S, Park J, Pandey D K, Clift P D, Kulhanek D K, Steinke S, Griffith E M, Suzuki K and Xu Z (2019) Variations in $\delta^{13} \mathrm{C}$ values of sedimentary organic matter since late Miocene time in the Indus Fan (IODP Site 1457) of the eastern Arabian Sea. Geological Magazine doi. org/ 10.1017/S0016756818000870

Kotla S S, Patnaik R, Sehgal R K and Kharya A (2018) Isotopic evidence for ecological and climate change in the richly fossiliferous Plio-Pleistocene Upper Siwalik deposits exposed around Chandigarh, India Journal of Asian Earth Sciences 163 32-42

Kroon D, Steens T and Troelstra S R (1991) Onset of monsoonal related upwelling in the western Arabian Sea as revealed by planktonic foraminifers $I n$ : Prell W L, Niitsuma N et al. (eds.), Proceedings of the Ocean Drilling Program, Scientific Results, College Station, TX Ocean Drilling Program 117 257-263

Kumaravel V, Sangode S J, Kumar R and Siddaiah N S (2005) Magnetic polarity stratigraphy of Plio-Pleistocene Pinjor Formation (type locality), Siwalik Group, NW Himalaya India Current Science 88 1453-1461

Kutzbach J E, Guetter P, Ruddiman W and Prell W (1989) Sensitivity of climate to late Cenozoic uplift in southern Asia and the American west: Numerical experiments Journal of Geophysical Research Atmospheres 94 1839318407

Kutzbach J E, Prell W L and Ruddiman W (1993) Sensitivity of Eurasian climate to surface uplift of the Tibetan Plateau The Journal of Geology 101 177-190

Molnar P, Boos W R and Battisti D S (2010) Orographic controls on climate and paleoclimate of Asia: thermal and mechanical roles for the Tibetan Plateau Annual Review of Earth and Planetary Sciences 38 77-102

More S, Paruya D K, Taral S, Chakraborty T and Bera S (2016) Depositional Environment of Mio-Pliocene Siwalik Sedimentary Strata from the Darjeeling Himalayan Foothills, India: A Palynological Approach PLoS ONE 11 doi. org/10.1371/journal.pone.0150168

Patnaik R, Gupta A K, Naidu D, Yadav R R, Bhattacharyya A and Kumar M (2012) Indian monsoon variability at different time scales: Marine and terrestrial proxy records Proceedings of the Indian National Science Academy 78 535-547

Patnaik R and Prasad V (2016) Neogene climate, terrestrial mammals and flora of the Indian Subcontinent Proceedings of the Indian National Science Academy 82 605-615

Prell W L and Kutzbach J E (1997) The impact of Tibet-Himalaya elevation on the sensitivity of the monsoon climate system to changes in solar radiation, In Ruddiman W F (ed.), Tectonic uplift and climate change: New York, Plenum Press, pp 172-203

Quade J, Cerling T E and Bowman J R (1989) Development of Asian monsoon revealed by marked ecological shift during the latest Miocene in northern Pakistan Nature 342 163166

Routledge C M, Kulhanek D K, Tauxe L, Scardia G, Singh A D, 
Steinke S and Saraswat R (2019) A revised chronostratigraphic framework for International Ocean Discovery Program Expedition 355 sites in Laxmi Basin, eastern Arabian Sea Geological Magazine doi. org/10.1017/ S0016756819000104

Satpathy R K, Steinke S and Singh A D (2019) Monsoon-induced changes in surface hydrography of the eastern Arabian Sea during the early Pleistocene Geological Magazine doi.org/ $10.1017 / \mathrm{S} 0016756819000098$

Sharma V and Srinivasan M S (2007) Geology of AndamanNicobar: The Neogene Capital Publishing Company 1163

Singh A D, Jung S J A, Darling K, Geneshram R, Ivanochko T and Kroon D (2011) Productivity collapses in the Arabian Sea during glacial cold phases Paleoceanography 26 PA3210 DOI: $10.1029 / 2009$ PA001923

Singh AD, Naidu P D and Saraswat R (2016) Indian Contributions to Marine Micropaleontology (2010-2015) Proceedings of the Indian National Science Academy 82 663-673

Singh A D, Jung S J A, Anand P, Kroon D and Ganeshram R S (2018) Rapid switch in monsoon-wind induced surface hydrographic conditions of the eastern Arabian Sea during the last deglaciation Quaternary International 479 3-11

Srinivasan M S and Singh A D (1991) Planktonic foraminiferal evidence for the Neogene paleoceanographic changes in the Indian Ocean In Ann Tech Meet and IGCP-246, Chiang Mai Univ Thailand 179-205

Srivastava G, Paudayal K N, Utescher T and Mehrotra R C (2018a) Miocene vegetation shift and climate change: evidence from the Siwalik of Nepal Global and Planetary Change 161 108-120

Srivastava G, Mishra S R, Barman P, Mehrotra R C and Tripathi S C (2018b) Lagerstroemia L. fossil wood from the Indus molasse sediments (possibly late Miocene) of TransHimalayan region and its phytogeographic and climatic significance Review of Palaeobotany Palynology 255 1421

Srivastava G, Tiwari R P and Mehrotra R C (2017) Quantification of rainfall during the late Miocene-early Pliocene in northeast India Current Science 113 2253-2257

Sun B, Wang Y-F, Li C S, Yang J, Li J F, Li Y L, Deng T, Wang S Q, Zhao M, Spicer R A, Ferguson D K and Mehrotra R C (2015) Early Miocene elevation in northern Tibet estimated by palaeobotanical evidence Scientific Reports 510379 doi: 10.1038/srep10379

Tada R, Irino T, Ikehara K, Karasuda A, Sugisaki S, Xuan C, Sagawa T, Itaki T, Kubota Y, Lu S and Seki A (2018) Highresolution and high-precision correlation of dark and light layers in the Quaternary hemipelagic sediments of the Japan Sea recovered during IODP Expedition 346 Progress in Earth and Planetary Science 5 doi: 10.1186/s40645018-0167-8

Tapponnier P, Zhiqin X, Roger F, Meyer B, Arnaud N, Wittlinger $\mathrm{G}$ and Jingsui $Y$ (2001) Oblique stepwise rise and growth of the Tibet Plateau Science 294 1671-1677

Tripathi S, Tiwari M, Lee J, Khim B K, IODP Expedition 355 Scientists (2017) First evidence of denitrification vis-a-vis monsoon in the Arabian Sea since Late Miocene Scientific Reports 743056 doi: 10.1038/srep43056

Wang B, Zheng H B, He Z, Wang P, Kaakinen A and Zhou X Y (2014) Middle Miocene eolian sediments on the southern Chinese Loess Plateau dated by magnetostratigraphy Palaeogeography, Palaeoclimatology, Palaeoecology 411 257-266

Wang P, Wang B and Kiefer T (2012) Global Monsoon across timescales Climate Dynamics 39 1043-1044 